\title{
The Word and the Stage, or the Intermediate Transparency in The Blood Knot by Athol Fugard
}

\section{Kerry-Jane Wallart}

\section{(2) OpenEdition \\ 1 Journals}

Electronic version

URL: https://journals.openedition.org/ces/5423

DOI: $10.4000 /$ ces.5423

ISSN: 2534-6695

Publisher

SEPC (Société d'études des pays du Commonwealth)

\section{Printed version}

Date of publication: 1 September 2012

Number of pages: 63-72

ISSN: 2270-0633

\section{Electronic reference}

Kerry-Jane Wallart, "The Word and the Stage, or the Intermediate Transparency in The Blood Knot by Athol Fugard", Commonwealth Essays and Studies [Online], 35.1 | 2012, Online since 18 April 2021, connection on 23 July 2021. URL: http://journals.openedition.org/ces/5423 ; DOI: https://doi.org/ $10.4000 /$ ces. 5423

\section{cc) (†) $\ominus$}

Commonwealth Essays and Studies is licensed under a Licence Creative Commons Attribution - Pas d'Utilisation Commerciale - Pas de Modification 4.0 International. 


\section{The Word and the Stage, or the Intermediate Transparency in The Blood Knot by Athol Fugard}

By staging the confrontation between two brothers, one black and one white, in a South African apartheid context, Athol Fugard complements traditional dramatic interrogations on the artificiality of social roles with a compelling political question. This paper focuses on the function of fables used as a Brechtian distancing device in order to transpose one story, one situation, one conundrum, into another. Such transfers are working towards associating a shock effect with understanding.

In The Empty Space, Peter Brook - the director who has staged Athol Fugard's Siqwe Banzi is Dead at the Bouffes du Nord theatre in Paris (2007) and whose film Meetings with Remarkable Men (1979) casts the South African playwright - states that theatre is the art that makes the invisible visible. ${ }^{1}$ Visibility does not entail anything obvious. Indeed, drama does rely heavily on masks and costumes, and not only in European traditions. Theatre, an artform that derives etymologically from the realm of sight, can be sketchily defined as an attempt to interrogate appearances on the one hand, and their specific hermeneutics on the other. Put differently it calls into question the relation of perception and interpretation. If theatre is performed in real time and in the real world, what is shown on stage reaches us through a series of screens, lenses and filters, through a distance that no avant-garde experiment could fully abolish. There is the gap between actors and the audience but also that of language, between signified and signifier. ${ }^{2}$ More perhaps than any other art, theatre allows us to understand the link between sight and knowledge that is betrayed by such expressions, often to be heard on Athol Fugard's stage, as "you see," hinting not at sight but at comprehension. They could suggest that such "visual" understanding be immediate, while the duration and diffraction that drama implies tell another story. If all art is a supplement to nature, ${ }^{3}$ the stage is both using and denouncing a closeness unequalled by any other artistic practice. The layers of artificiality and all the self-designation never completely suppress the feeling that the table, the chair, the bed and above all the body on stage are taken from real life, however the latter may be defined.

Peter Brook's statement applies all the better to the plays by South African playwright, novelist and film director Athol Fugard since the gaze is not hindered by all the bourgeois clutter of things that belong to the "Deadly Theatre" (Brook 11-46). There is actually not much to see in his plays whose stage is not physically crammed to say the very least. In The Blood Knot, as in quite a lot of other plays by Fugard, there are two actors and scant stage business. Like the Beckettian have-nots who are more or less their contemporaries ${ }^{4}$ Morris and Zach make do with very little, and when Morris - whose name, suggesting "more," is highly misleading - ungainly thinks of leaving the confron-

1. The definition of the "Holy Theatre," also called "The Theatre of the Invisible-Made-Visible," is that "the stage is a place where the invisible can appear" (47).

2. This paper excludes the marginal, but thrilling, experimentations in utterly speechless theatre (Samuel Beckett's Breath e.g.).

3. The now common notion of supplement needs to be traced back to Derrida 144-5.

4. As he was writing The Blood Knot, Athol Fugard was also directing Waiting for Godot (Fugard Notebooks 65). 
tation $^{5}$ that constitutes the entire play, he merely takes his Bible, his "other shirt" and his alarm-clock $(7,84) .^{6}$ The mention of the Bible is here of crucial interest because it introduces a central intertext, that of the fable of Cain and Abel. Zach and Morris are brothers who are both bent on murdering the other in metaphorical terms. The "other shirt" sends us back to the game of identity theft that launches much of the action in what can largely be read as a comedy of errors, the two brothers impersonating each other in turn in post-Shakespearian manner. Lastly, the alarm-clock represents not so much time as delay, procrastination, an extension of duration that characterizes much of what takes place in the play. The opposite conception and representation of time, immediacy, would designate the instantaneity with which light goes through a transparent obstacle, an absence of deformation that is a constant and ever protracted horizon for Morris and Zach. Such visual dereliction makes room for what is mostly there to be seen without any apparent screen, i.e., the difference in skin colour. Although they have the same parents, Morris looks white whereas Zach looks black. From such immediate impressions there derives a social, cultural, political identity in an apartheid society. I shall attempt to show that Fugard tries to revive the immediacy of the perception through an avoidance of such constructed identities, mostly by using Brechtian devices of fabulation and transposition.

Here is a brief overview of the plot: the brothers spend days and, increasingly, nights, talking about both past and future until Morris suggests that Zach write to a pen-friend. The latter, Ethel Lange, turns out to be a white woman. She becomes both a fantasy and a threat, the object of a legal crime in apartheid South Africa. ${ }^{7}$ She never appears in the flesh but becomes the prism through which each brother projects the existence of the other one. There is no possible reliance on appearances in the play, only diffractions and refractions. Ethel is not the only ghost that works as a filter. There are Minnie, a friend of Zach's; Connie, his former girlfriend; an employee at a gas station; a man briefly seen on a road and last but not least their mother, an absence that creates more and more mediation and which remains a mystery for the spectator. All of these spectres are projections of the two brothers who lend them various attributes when they are not borrowing them. A game of mirrors, appearances, masks and crisscrossing roles $^{8}$ is introduced that creates a whirlwind of representations for which the bareness of the stage and the physical dereliction of the protagonists had not prepared the spectators. The existentialist screen would seem to foreclose the very possibility of transparency while multiple and variable identities pile up under our very eyes. Such a paradox is redoubled by the opposition between faux-semblants in the plot and the concreteness of theatre.

5. The verbal struggle between the two brothers recalls as much Beckett as Sartre and even more so Albert Camus, a distinct influence on Athol Fugard to which the Notebooks recurrently attest (56, 61, 73, 82, 94, 104-7, 156, 195). The Notebooks are a precious source of information since the first hundred and fifty pages are largely concerned with the writing, performing and reception of The Blood Knot.

6. All references to the play will include the scene and page numbers between brackets.

7. The notorious Immorality Act, a hallmark of the apartheid apparatus, deemed any relationship between Whites and "Coloureds" a crime.

8. This dimension of the play provoked the scathing criticism of Dennis Walder: «The idea that humiliation and role-playing are essential for survival permeates Fugard's plays» (62); «The Blood Knot [...] suggest[s] an acceptance of inhumanity and prejudice as permanent features of life. Fugard's own sense of the individual's relationship into society and to history is fundamentally pessimistic" (100). My argument here is that "role-playing" is highly unstable, preventing any such "sense of the indiviual's relationship into society." 
This paper focuses on the ways in which the stage is used in The Blood Knot to denounce the extent to which the racist, undemocratic, apartheid-ridden South Africa has rendered vision highly problematic or even impossible. It interrogates the onrush of affects, feelings and emotions in social dealings. In The Blood Knot, emotions are often mediated but the playwright is seeking an immediate response from the audience. My concern will finally be to explore in which ways such immediacy can paradoxically be reached through language, through its connotative - as opposed to its denotative - value. The point is that if theatre traditionally and theoretically relies on the transparency of the stage and the opacity of the word, in The Blood Knot, the "real" has become highly problematic, forcing transparency to find a provisional shelter in language.

The two protagonists, Morris and Zachariah, are all but reduced to their skin colour, something which actually launches the dramatic action. The conventional characterization that goes through the elements of the well-made play inherited from the European nineteenth century (e.g., social class, age, last name, profession, connections, past occupations) are all carefully avoided all the better to highlight the opposition between a black and a white man. The relationship of domination and submission, the scheme of the pen friend revolve around skin colour. This being said, roles have a tendency to migrate. The play is actually much about trying on the other's identity - in South African English, one is said to "try" for white. While Morris, who looks white, is coming back to his childhood township from a year spent among whites literally to put on Zach's clothes $(1,21)$ and experience life as a Coloured, Zach corresponds with Ethel by pretending to be white, which is her colour and the only one acceptable and legally possible for her pen-friend. ${ }^{9}$ It turns out that being black or white is largely the prerogative of outfits and appearances, in the first case, and of literacy in the other. The Sartrian recognition of the master by the slave becomes that of the white by the black - a configuration that was, after all, much scrutinized by the father of existentialism in his preface to Fanon's The Wretched of the Earth. The play pinpoints the impossibility for black and white to remain what they are, just colours. The crime of South African colonialism is enacted throughout the play in various forms, including a financial one. Morris, indeed, takes the money earned by Zachariah, and plans to buy a farm with it, thus performing the land dispossession at stake on a national scale during apartheid but also before and after.

Moreover, the play introduces the tragic transgression, or hubris, through the seminal biblical fratricide of Abel by Cain. Such a crime may be seen on a first level as the epitome of the apartheid regime where the white brother killed the black one and stole his belongings. The Scriptures are actually quoted by Morris while Zach is sleeping, Abel-like indeed.

\section{He returns to the table, picks up the Bible, and after an inward struggle speaks in a solemn, "Sunday" voice. \\ And he said: "What hast thou done? The voice of thy brother's blood crieth unto me!" Morris drops his head in an admission of guilt. \\ Oh Lord! Oh Lord! So he became a hobo and wandered away, a marked man, on a long road, until a year later, in another dream, He spake again: Maybe he needs you, He said. You better go home, man! Pause (1, 19)}

9. A watershed in Fugard's production, The Blood Knot was also a landmark in South African drama since it brought a black and a white actor together on the same stage. This was innovative and was declared legal only four years later along with non-segregated audiences (see Wertheim 18). 
Here, after the symbolical murder of Zach who has unexpectedly fallen asleep, and thus assumes the motionlessness of death, the role-shifting is between Morris and no less than God, since he utters the very words the Lord addresses to Cain. If Morris poses as a murderous brother he also speaks "as" God, as is made obvious on stage by his counterfeit voice, a cheap and comic reproduction of the idea commonly conveyed of "God's voice." He then goes on in the same role but decides this time to write the cue himself rather than rely on the Scriptures. The whirl of role-shifting is further propelled by the disjunction between a pastiche of the English the King James version Bible had been penned in ("he spake") and the very words of God, whose register is quite colloquial ("hobo," "man" as an apostrophe and expression of familiarity). God is now speaking like Morris, and Morris like God. This comes in blatant contradiction with the stage direction where Morris "admits" his guilt. It thus seems that the stage does not lie when words do. The gestures of Morris (the "inward struggle," the dropping of the head) point to his symbolical murder of his black brother while his tone and his cues attempt at obfuscating the identity of the culprit, even as apartheid was based on an obvious but unsayable inversion where the murderer ruled, including the law, while the victim remained oppressed. I wish, however, to interrogate the status of the fable, or parable, in the play. It is a technique that has been frequently borrowed from Bertolt Brecht, such a major influence that Athol Fugard had named his first company "The Circle Players," a tribute to the Caucasian Chalk Circle. ${ }^{10}$ A fable can be defined as the deployment of a story that clearly echoes another context and that requires from the reader or spectator a systematic act of transposition. If the "admission of guilt" shown on stage by Morris seems telling, it is only through the mediation of the story of Cain and Abel that the spectator spontaneously adapts to what is on stage. Thus, the status of the stage and its semantic, non-linguistic signs can be seen as intermediate, oscillating between immediacy and mediation. Like the transparent lens, it lets meaning come through without major distortions though it provides for a gap and a delay.

Transparency is the filter of the fable that helps us decipher the action. It is a world of false appearances that point to some truth having to do with the tragedy of racial selves in apartheid South Africa. Colours prevail, disregarding the true identity since the two men have the same mother and father, and thus share the same genetic makeup. Yet even those appearances happen to morph constantly, suggesting that there is no such thing as a true identity. The versatility of roles is briefly denied by Zach: "Because from now on, I'll be what I am. They can be what they like" $(4,63)$. Such a statement is followed by a problematic decision to stand apart mingled with outrageous eugenic statements: "I don't want to mix. It's bad for the blood and the poor babies. So I'll keep mine clean, and theirs I'll scrub off, afterwards, off my hands, my unskilled, my stained hands" (4, 63). Meanwhile, a more realistic - as it were - Morris reminds us of his own complicated, opaque identity: "I asked his name. Kleinbooi. But he didn't ask mine. He wasn't sure, you see. So often in my life they haven't been sure, you see" $(4,63)$. The understanding that ought to follow from visual evidence is seriously called into question.

10. The play was rehearsed by Fugard and his actors in 1964 before the performance was delayed by the arbitrary and violent arrest of the actor playing Azdak, Norman Ntshinga, a black school-teacher who would spend two years in jail (most of that time in the notorious prison of Robben Island), accused of supporting the banned African National Congress. This episode partly inspired The Island, a later play by Athol Fugard. On Brecht's influence on Fugard see e.g., Kruger 215-79. 
In the play the white brother, Prospero-like, reads to his illiterate black brother but, on the other hand, he is the one who stays home, cleans the house, mends torn clothes and bathes the black brother's feet after a day of hard work. This migration of roles finds metatheatrical echoes in the way Athol Fugard was known to work. He belonged to a tradition of workshop plays where the black actors would contribute to the process of writing, and where the usually white stage director would sometimes climb on the stage to play a role (Crow 100-1). What is left, importantly, in terms of stability, is the Sartrian notion of "for the other," the idea that we behave according to the other person. As early as the opening stage directions, a happy Zach modifies his expression upon seeing Morris smiling: "He frowns, pretends to think, and makes a great business of testing the water with his foot" $(1,3)$.

I shall now argue that such versatility is linked to time, revealing not so much that we are never the same as time goes by as the fact that history has stopped, leaving no possibility for meaning to stabilize. The intermediate clarity of transparency is made impossible by the very distance it carries along. A few minutes after the beginning of the play its two protagonists embark upon a lengthy evocation of a certain Minnie, a man they used to know. The name can be heard as a distortion of "me," that impossible self, while the central and double " $n$ " call forth ideas of negation. It so happens that the memory of Minnie is fully and obsessively entwined with temporal notions: not only is he a person they no longer see but he would "sit all night" $(1,7)$, "come every night" $(1,7)$ or just on Fridays ("Friday nights it was," 1, 8), he knew "the good times" $(1,8)$, could play the guitar "non-stop" $(1,8)$. He comes with "Golden Moments at two bob a bottle" $(1,9)$ in his hand - thus designating a time that is precious and cheap at once, a contradiction in terms. He stands there and says, "tonight is the night" $(1,9)$. Furthermore, the stage directions indicate that the end of this speech coincides with the ringing of Morris' alarm clock. The memory is strong enough in Zach's mind for him not to be able to listen to the plans of Morris, who is thinking about their future farm. From that point onwards, the entire action of the play is filtered through the screen of what has already happened and what could take place, none of it being staged in front of us. Incidentally, the treatment of time, in Morris's conception, also entails space, since he wished to buy "large, blank spaces" $(1,10)$ in order to start a farm. The comedy of errors that is unfolding in front of us is thus dependent on the passing of time - Morris, who used to pass himself as white, and no longer does, is one blatant example thereof.

This is another instance where the apparent reliability of the stage, its concreteness, is belied. Like colour, time has been made deceitful in apartheid South Africa because the regime has rewritten a past that never existed, foreclosing any possibility for change, political, social and otherwise. I suggest that this is the reason for the blatant absence of context in the play. Athol Fugard's skill as a playwright is to do away with history: in this profusion of time indications, there is a puzzling and very Beckettian absence of dates in the play with absolutely no element allowing us to situate the play in time, let alone any precise reference to the apartheid system. Time is frozen or else described in terms of delay, belatedness, the better to represent the state of a country where the catastrophe has taken place without there being any hope. The following exchange addresses questions of identity and links them systematically to notions of time and, more particularly, of duration and delay: 
ZACHARIAH Wait, Morrie!

MORRIS It's late.

ZACHARIAH I want to have a good look at you, man.

MORRIS It's a bit late in the day to be seeing your brother for the first time. I been here a whole year, you know.

ZACHARIAH Ja. But after a whole life I only seen me properly tonight. You helped me.

I'm grateful.

MORRIS It was nothing...

ZACHARIAH No! I'm not a man that forgets a favour. I want to help you now.

MORRIS I don't need any assistance, thank you.

ZACHARIAH But you do. A man can't really see himself. Look at me. I had an odd look at me in the mirror - but so what? Did it make things clearer? No. Why? Because it's the others what does. They got sharper eyes. I want to give you the benefit of mine. Sit down. (Morris sits) $(4,64)$

Delay is associated with negations ("nothing," "not a man," "I don't," "a man can't"), as in the case of "Minnie." In the Notebooks, Athol Fugard goes as far as saying that we are witnessing the death of both characters on stage: "The blood tie linking them has chained them up. They are dead or dying because of it" (10). ${ }^{11}$ The oscillation between a completed action and an action in progress is rendered by the gerund that reinforces the idea of duration and the belatedness of events.

The foregrounding of a delayed, never-ending temporality has consequences on the generic level, as Athol Fugard has himself analyzed and deplored in reflections sprung from a screening of $A$ View from the Bridge by Arthur Miller:

Why has the tragic dimension been lost in modern playwriting, where has it gone? [B] ecause of our assault on our concept of finality, the end - FINIS. [...] By trying to eliminate "THE END” I have unwittingly assaulted the tragic dimension. (Notebooks 76)

Indeed and despite the tragic hubris of a metaphorical fratricide, both brothers keep projecting onto their imaginary screen the dream of a new view, a new beginning: "I reckon it's one of the hard things in life to begin again when you're already in the middle" $(1,14)$. If Morris describes autumn, its yellow dust, the absence of birds, he also steels himself by saying it is "only the beginning of the end of another year" $(1,20)$.

I shall now argue that the play The Blood Knot actually operates a return to the tragic genre and structure through Brechtian defamiliarization. As a result, life literally seems to end with the intrusion of certain images that cannot be transparent if they are to produce an effect. Their function has to do with the obstacle but also consequently and not so paradoxically with earnestness. On this page about tragedy Fugard contends that it is involved with retrieving one's own conscience and truth, and he denounces Eddie's "self-deception," his meaningless words. The paradox is that for truth to appear one needs "the dark shadow of tragedy" (Notebooks 76). Through images the playwright attempts to render the first shock, that of the apartheid to an outsider. If skin colour is already deep-rooted in prejudice and has become transparent, no longer seen for what it is but as what has been constructed behind it, images reactivate a shock effect. The result is one of defamiliarization, another point where Fugard draws on Brecht's theories. In the final scene, during which Morris and Zachariah actually play at being respectively the white master and the black servant, Morris declares:

11. This death-in-progress was experienced by the author who recalls writing The Blood Knot in a small flat on Bird Street, Port Elizabeth, while his father was agonizing in the other room. Meanwhile, his wife Sheila was going through another sort of duration, since she was expecting (see Fugard Notebooks 41). 
You see, you bothered me as I passed. Moments of recognition, you know, at first sight, and all that. So I'll take this road. I mean ... I'll have to get away if I want to admire the beauty, won't I? Yes. It's a good road. (7, 90, italics mine)

He thus expresses the necessity for distance and delay in the "admiring" of sights, here the road. His words link ideas of disturbance ("bothered") with knowledge ("recognition"), again connected with sight ("you see"). They string together vision ("at first sight") and confusion ("and all that"), and they create a metaphor for defamiliarization ("I'll have to get away"). Central in this passage is the ellipsis, a paradoxical trope which is transparent and opaque all at once: the speaker and the audience ought to understand the same thing without there being any need to speak, or alternatively, the speaker does not even know what the apt word may be. What follows these lines is a reinforcement of the idea of distance:

"It's going places, because ahead of me I see the sky. I see it through the trees ... so I'm climbing up the hill in this road, putting miles between us; and now, at last, there ahead of me is the sky, big blue." $(7,90)^{12}$

The character's vision runs against the grain of the very idea of theatre, since it cannot be staged and shown to the audience. It is also a passage about distance, "miles between us" and filters "through the trees." More than anything, it expresses a desire to see the world anew and to provoke the spectators into thinking about man in terms that are not racial.

Images thus seem to function as a counterpoint to the betrayal of stage semantics in the play. There are Eliotesque images such as "the sadness of shoes without socks, or no shoes at all" $(4,62)$, binding human emotions and objects or human parts. Feet happen to be frequently mentioned in the play, especially in the following quote where Morris is reading Ethel's letter to Zach,

MORRIS (reading) "Dear Zach, many thanks for your letter. You asked me for a snap, so

I'm sending you it. Do you like it? That's my brother's foot sticking in the picture behind the bench on the side..."

ZACHARIAH She's right! Here it is.

MORRIS “Cornelius is a ... policeman” $(3,41)$

A metonym for movement, the foot can be linked to the distance previously identified. It has also been the attribute of tragedy ever since Oedipus (and his "twisted foot" after the manner in which his parents are said to have hanged him from a tree in order to kill him in his infancy) so that the playwright hints here that the policeman might not be representing so much a social justice as a dramatical one. The play features other transpositions (a foot for a face, a man for a woman) but more importantly, Cornelius represents another brother. In any case, the allusion confirms and heightens the atmosphere of fear that prevails in the play and that is first and foremost the one that each brother arouses in the other: "I got a fright" $(1,12)$, Zach says upon Morris's arrival. This photograph encapsulates the paradox delineated previously: it requires the transparency of a lens but also a lapse of time, a delay, in order to develop (even though it is taken in a "snap"). Photography also plays an important role in Sizwe Banzi is Dead, and despite (or through) the notion of delay that it carries in its wake, with the very death

12. Such - obviously impossible - final vision comes full circle with the road, leading nowhere, evoked in the first scene by Morris, "City streets lead nowhere ... just corners and lampposts" $(1,10)$. 
of the eponymous character and his pictorial reincarnation, it is precisely the place of the audience's most immediate reaction, as noted by Fugard:

After watching the first few seconds of the operation [putting Sizwe's photograph into Zwelinzima's pass] in stunned silence a voice shouted out from the audience: "Don't do it brother..." Another voice responded "Go ahead and try. They haven't caught me yet." That was the cue for the most amazing and spontaneous debate I have ever heard. As I stood listening to it all, I realized I was watching a very special example of one of theatre's major responsibilities in an oppressive society: to break the conspiracy of silence. The action of our play was being matched by the action of the audience. A performance on stage had provoked a political event in the auditorium. (Notebooks 31-2)

It seems both problematic and crucial that the audience should react with such passion at a moment when what is being scrutinized (a photograph) cannot be seen by them. I wish to link this moment with the close analogy that Peter Brook draws between a theatrical experience and the picture in the pages he dedicated to what he calls "Immediate Theatre":

I know of one acid test in the theatre. It is literally an acid test. When a performance is over, what remains? [...] The event scorches on to the memory an outline, a taste, a trace, a smell - a picture. [...] When years later I think of a striking theatrical experience I find a kernel engraved on my memory: two tramps under a tree, an old woman dragging a cart, a sergeant dancing, three people on a sofa in hell ${ }^{13}$ - or occasionally a trace deeper than any imagery. (Brook 152)

The picture of Cornelius' foot may be seen as a metatheatrical representation of the effect of the whole play onto the audience, encapsulating the terror inspired by the apartheid regime as well as its truly tragic dimension.

As opposed and by contrast to the audience's impressions, knowledge is not immediate on stage, to the utmost despair of both characters. Zachariah thus exclaims, quite ungainly as he well knows, "What I want to know now, right this very now" (12). The substantification of time and its adverbs ("this very now" where one would expect "this very minute") displaces onto the linguistic plane what is impossible from a pragmatic point of view. Whereas the signs from the stage cannot free the spectator from a viewpoint inherited from the apartheid regime, language can cross such borders. Changing the categories of grammar only further defamiliarizes us spectators from the world as it stands. Language, on the contrary, reaches into the affect and the human body that is otherwise too caught in processes of understanding. I wish to show in the last part of this paper that if images offer an immediate perception, language represents a mediation which is still efficient in dramatic terms.

Linguistic distance can be found in the ubiquitous polyglossia in Athol Fugard's works. A line in the introduction to the play warns that "an important element in my own writing is this question of 'translating' from Afrikaans to English" (xx). One could also dwell on the importance of names in the apartheid society where one finds a baas or baasie, and on the other hand bantoes, capie, hotnot, meid, kaffer, all of which are to be heard at one point or another in the play, so that roles come with a name and only exist through linguistic categories. What I would like to scrutinize now is the way in which the extension of time alluded to earlier is also filtered through language, as in this statement,

13. As in life there are no coincidences on the stage and the reader will have recognized three playwrights who appear in this paper, Beckett, Brecht and Sartre. 
"A whole year of spending tonights talking, talking. I'm sick of talking. I'm sick of this room" (13). This is a metatheatrical discourse on acting, a description of the actor trapped on stage at night and expected to speak. It also agrammatically declenses the adverb "tonight," turning it into a noun. Language is so linked to time that it becomes its only measure. If the play extends over several days the stage directions remain vague ("a few days later," etc.). The only measure is that allowed by the going back and forth of letters between Zach and Ethel Lange (her name evoking both language and time). Her being found in the newspaper is another inscription of text in temporality - a newspaper article being a text written on a given day and whose validity is thus guaranteed.

With Ethel's letters as with the photograph, we cannot see what the characters do. The resulting opacity is once more linked with delay but fails to hide the ultimate absence of meaning, as in the following:

ZACHARIAH (bluff indignation) Burn this letter! What's wrong with this letter? MORRIS Ethel Lange is a white woman!

ZACHARIAH Wait ... wait ... wait ... not so fast. I'm a sort of slow man. [...] Think of Ethel, man. Think! Sitting up there in Oudtshoorn with Lucy, waiting ... waiting ... for what? For nothing. $(3,43-4)$

The waiting is geared towards the end and the town of Oudtshoorn sounds singularly close to "Outa," or "old man" in Afrikaans. As in Beckett's plays, the beginning and the end are conflated with the second cue starting with "Last night," including an adverb that also points to duration, and the last stage direction showing Morris moving to his bed, in the attitude he had when the curtains were first raised. Past and future constantly fuse into each other while the few attempts to avoid such contagion are doomed to failure. One of them is the amazing scene 6, a monologue by Zach (81-2) that expresses the ideal of a transparent language, one that would be wrenched away from temporality. Unfortunately, it is fictitious on at least two grounds, one being that is an imaginary dialogue with their mother, the second that he is actually pretending to be Morris.

MORRIS You look tired tonight, old man. (Zachariab looks at him askance) Today too long? I watched you dragging your feet home along the edge of the lake. I'd say, I said, that that was a weary body. Am I right, old fellow?

ZACHARIAH What's this "old fellow" thing you got hold of tonight?

MORRIS Just a figure of speaking, Zach. The shape of round shoulders, a bent back, a tired face. The Englishmen would say "old boy" ... but we don't like that "boy" business, hey?

ZACHARIAH $\mathrm{Ja}$. They call a man a boy. You got a word for that, Morrie?

MORRIS Long or short?

ZACHARIAH Squashed, like it didn't fit the mouth.

MORRIS I know the one you mean.

ZACHARIAH Then say it.

MORRIS Prejudice.

ZACHARIAH Pre-ja-dis.

MORRIS Injustice!

ZACHARIAH That's all out of shape as well.

MORRIS Inhumanity!

ZACHARIAH No. That's when he makes me stand at the gate. $(3,35$, bold characters mine)

The length of the day becomes that of the word, underpinning the link between the mediation of time and that of racial oppression. Like a Shakespearean conceit, the body itself becomes an alphabet of the injustice at stake in South African society, the "thing" 
that no other human language could express. Even language is objectified ("this 'old fellow' thing"').

What else is there? Sister. Sissy, they say, for short. Like something snaky in the grass, hey? But we never had one, so we can't be sure. You got to use a word a long time to know its real meaning. That's the trouble with "Mother". We never said it enough.

(He tries it.) Mother. Mother! Yes. Just a touch of sadness in it, and maybe a green dress on Sundays, and soapsuds on brown hands.

[...] But brothers! Try it. Brotherhood. Brother-in-arms, each other's arms. Brotherly love.

Ah, it breeds, man! It's warm and feathery, like eggs in a nest $(1,19)$

Thus scattered in the play are clues to the pre-Saussurean idea and ideal of a natural language. Such transparency is unattainable because language, let alone reality, acts as a strong filter that literally shapes the world. The play primarily catches the moment when language is still an emotion, just like the foot on the picture may be, even after history and human monstrosity have prevented us from seeing the other for what he or she is. Words are associated with a feeling, an affect, an impression - an image, after all.

As an optical phenomenon, transparency describes a crossing, a trajectory, that of light through something that does let it through. Transparency implies distance, however short. It entails temporal and spatial extension. The indefatigable quandary in The Blood Knot is that of the use of such distance in order to reactivate our perception of apartheid as a moral scandal, both through images and words. The art of the theatre appears here as both a solution and a complication: a solution, because its very nature allows a discourse on masks better to be deployed and a complication since it acts as yet another screen. It might, however, be a very appropriate medium to translate the nature of transparency, both a promise of clarity in our vision and an awareness of misleading appearances. A committed play "cluttered with the debris of thirty years of cowardice, brief courage, blindness, deafness" (Notebooks 44) The Blood Knot combines the immediacy of sight and the mediation of the letter to re-activate senses and re-invent common sense.

Kerry-Jane WALLART

University of Paris-Sorbonne

\section{Works Cited}

Brook, Peter. The Empty Space. 1968. Harmondsworth: Penguin, 1972.

Crow Brian with Chris Banfield. "Athol Fugard." An Introduction to Post-Colonial Theatre. Cambridge: Cambridge UP, 1996. 96-111.

DerridA, Jacques. Of Grammatology. Trans. G.C. Spivak. Baltimore: Johns Hopkins UP, 1976.

Fugard, Athol. The Blood Knot. 1963. Cape Town: Oxford UP, 1992.

—. Notebooks 1960/1977. Ed. Mary Benson. London: Faber, 1983.

—. "Sizwe Banzi is Dead." A Night at the Theatre. Ed. Ronald Harwood. London: Methuen. 21-33.

Jeyifo, Biodun. "The Reductive 'Two-Hander' Dramaturgy of Athol Fugard: Aspects of the Art and Society Dialectic." The Truthful Lie: Essays in a Sociology of African Drama. London: New Beacon, 1985. 98-104.

Kruger, Loren. Post-Imperial Brecht, Politics and Performance, East and South. Cambridge: Cambridge UP, 2004.

WaLder, Dennis. Athol Fugard. London: Macmillan, 1984.

WertheIm, Albert. The Dramatic Art of Athol Fugard, From South Africa to the World. Bloomington and Indianapolis: Indiana UP, 2000. 